\title{
WOOD ANATOMY OF SEVEN SPECIES KNOWN AS “PAU-PARA-TUDO” IN BRAZIL
}

Keywords:

Wood identification

Pau-para-tudo

Medicinal plants

Secondary xylem

Histórico:

Recebido 27/01/2016

Aceito 19/07/2016

Palavras chave: Identificação da madeira

Pau-para-tudo

Plantas medicinais

Xilema secundário

Correspondência: clauleme09@gmail.com
ABSTRACT: Different medicinal plant species can be sold under the same common name. Considering the importance of the correct identification, this study aims to separate, using wood anatomy, seven species popularly known as pau-para-tudo. The results show that Drimys brasiliensis is separated from the others by the presence of tracheids. Capsicodendron dinisii hhas scalariform perforation plates and oil cells associated with the axial parenchyma. Axial parenchyma paratracheal vasicentric and in marginal bands beyond the rays' width, can separate Osteophoeum platyspermum from Simaba cedron. Handroanthus serratifolius has the unique presence of the axial unilateral paratracheal parenchyma and storied cell elements (parenchyma, fibers and vessel elements). Rauvolfia sellowii and Leptolobium dasycarpum can be separated by the number of square/upright marginal ray cells, greater in Rauvolfia sellowii. Thus, this work shows that wood anatomy is a valuable tool for species separation, helps with the identification and consequently is important for the quality control of plant product.

\section{ANATOMIA DA MADEIRA DE SETE ESPECIES CONHECIDAS COMO “PAU- PARA-TUDO" NO BRASIL}

RESUMO: Diferentes espécies medicinais de plantas podem ser vendidas com o mesmo nome popular. Considerando a importância de uma identificação correta, este estudo tem por objetivo separar, utilizando a anatomia de madeira, sete espécies conhecidas como pau-para-tudo. Os resultados mostram que Drimys brasiliensis é separada das outras espécies pela presença de traqueídes. Capsicodendron dinisii apresenta placa de perfuração escalariforme e células oleíferas associadas ao parênquima axial. Parênquima axial paratraqueal vasicêntrico e em faixas marginais alem da largura dos raios, separa Osteophoeum platyspermum de Simaba cedron. Handroanthus serratifolius é a única das espécies que apresenta parênquima axial paratraqueal unilateral e elementos estratificados (parênquima, fibras e elementos de vaso). Rauvolfia sellowii e Leptolobium dasycarpum podem ser separada pelo número de células marginais quadradas e eretas, maiores em Rauvolfia sellowii. Assim, este trabalho mostra que a anatomia de madeira é uma ferramenta valiosa para a identificação das espécies e é importante consequentemente para o controle de qualidade do produto vegetal. 


\section{INTRODUCTION}

Medicinal plants are used in large scale owing to its low cost and ease of acquisition (PRESIBELLA et al., 2003). In some cases, different species are commercialized under the same common name. Saw wood of Drimys brasiliensis Miers. (Winteraceae), Capsicodendron dinisii (Schwacke) Occhioni (Canellaceae), Osteophloeum platyspermum (Spruce ex A.DC.) Warb. (Myristicaceae), Rauvolfia sellowii Mull. Arg. (Apocynaceae), Simaba cedron Planch. (Simaroubaceae), Handroanthus serratifolius (Vahl) S.O.Grose (Bignoneaceae) and Leptolobium dasycarpum Volgel (Leguminosae), known as "pau-paratudo" or "pau-pra-tudo" (wood-for-everything), are sold as medicinal plants in open markets in Brazil (BARTH; BARBOSA, 1976; CAVALCANTE, 1983; SIENNA, 2008; BARATTO et al., 20I0; SEGOVIA et al., 20I I; TORRES et al., 20I0; LIMA et al., 20I I).

Among all these species, Drimys brasiliensis stands out as an effective anti parasitic agent, according to studies of bark and stem done by Corrêa et al. (20I I) and Claudino et al. (2013). Barrero et al. (2000) obtained essential oil from wood of $D$. winteri. Capsicodendron dinisii (synonym of Cinnamodendron dinisii Scwacke) is indicated as analgesic (painkiller) to treat toothache, and also to control vomiting, paralysis, as a stimulant for the treatment of migraines and to help with diseases of the uterus and vagina (RODRIGUES; CARVALHO, 2008). Andrade (20I3), proved the hemolytic effect of the essential oil from the leaves, stem and bark of this species. Anti-malarial activity was described for Simaba cedron by several authors, among them Moretti et al. (1994) and Oliveira et al. (2015) and a novel pentacyclic $\mathrm{C}$ (I9) quassinoid, cedronolactone $\mathrm{E}$ (I), was isolated from the wood of Simaba cedron by Hitotsuyanagi et al. (200I). Its structure was elucidated by interpretation of spectroscopic data. Rauvolfia sellowii has been described as having alkaloids in its composition, both in young stem and bark (PRESIBELLA et al., 2003; SIENNA, 2008; BARATTO et al., 2010). This species is also used in the treatment of diabetes, cholesterol control, and is also considered a hypotensive and digestive tonic (PRESIBELLA et al., 2003; SOUZA; FELFILI, 2006). Handroanthus serratifolius, in turn, whose one its synonym is Tabebuia serratifolia_(Vahl) G.Nicholson, presents in both bark and stem, anti-inflammatory, antimicrobial, anti-allergic, healing and anti-tumor properties (MORAIS et al., 2005; BITENCOURT et al., 20I4) and was described as having anti tripanossomial and leishmanial activity by GonzálezColoma et al. (2012).

The anatomical characterization of plants is an important tool for species identification. Although these species are known by the same common name, they have different chemical constituents and different anatomical properties. Studies on the anatomy of this species are scarce, except for the ones of Manieri (1958), Detienne and Jacquet (1983), Lisboa et al.(1984, 1987), Carlquist (1988), Alves and Algyalossy-Alfonso (2000, 2002), Miller (2007), Léon (2009), Trevizor (20II), Albuquerque (20I2) and Majcher (20I3) that qualitatively describes some of the species.

Whereas the authenticity of the plant is essential for their safe use in folk medicine and for the production of drugs, this study aimed to separate through wood anatomy, considering qualitative and quantitative parameters, seven species popularly known as "paupara-tudo" (wood-for-everything): Drimys brasiliensis, Capsicodendron dinisii, Osteophloeum platyspermum, Rauvolfia sellowii, Simaba cedron, Handroanthus serratifolius and Leptolobium dasycarpum.

\section{MATERIAL AND METHODS}

Wood samples of seven species, commonly known as "pau-para-tudo", from Dr. Calvin Mainieri Xylarium of the Institute for Technological Research of São Paulo (IPT), were analyzed: Drimys brasiliensis - Winteraceae (samples: IPT 6063 and 809), Capsicodendron dinisii Cannelaceae (samples: IPT 7436 and 7440), Osteophloeum platyspermum - Myristicaceae (samples: IPT 6627 and 9736), Rauvolfia sellowii - Apocynaceae (samples: IPT 4093 and 3200), Simaba cedron - Simaroubaceae (samples: IPT I4648, I997I and 19044), Handroanthus serratifolius - Bignoniaceae (samples: IPT I 3250, 20023 and 6624) and Leptolobium dasycarpum - Papilionoideae, Leguminosae (sample IPT 10702).

Histological sections were prepared on a microtome. Transverse and longitudinal sections (tangential and radial) were obtained with thickness ranging between 20 and 30 micrometers $(\mu \mathrm{m})$. The sections underwent clarification process, followed by double-staining procedure using astra blue and safranin or just safranin (KRAUS; ARDUIN, 1997). The stained and natural sections were submitted to a dehydration process in an ethanol series, immersed in n-butyl acetate, and then mounted on permanent slides with synthetic resin.

The anatomical description, which involved the quantitative and qualitative analysis, followed the IAWA list of microscope features (IAWA COMMITTEE, 1989). It was considered for the quantitative analysis the following features: vessel diameter and frequency; ray frequency, ray height and width (in micrometers and number of cell). Measurements were performed using 
all species samples except Drimys brasiliensis, which has tracheids and absent vessel elements. Quantitative results are showed by descriptive parameters averages, standard deviation and maximum-minimum values. An Infinity I camera coupled to an Olympus $3 \times 3$ I optical microscope (The Image Pro-Express 6.0 analysis program) was used and statistical analysis was undertaken following Silva and Azevedo (2002).

\section{RESULTS}

\section{Wood description}

Drimys brasiliensis (Figure IA-B): a). Growth ring boundaries indistinct or absent. b). Vesselless. c). Axial parenchyma absent or scarce diffuse. d). Rays uniseriate and multiseriate ( $2-7$ cells), of two distinct sizes and body ray cells procumbent mostly with 2-4 rows of square/ upright marginal cells.
Capsicodendron dinisii (Figure I C-H): a)Growth ring boundaries distinct, marked by thick-walled and radially flattening late wood fibers. b)Vessels diffuse, exclusively solitary, scalariform perforation plates, opposite intervessel pits and vessel-ray pits similar to intervessel pits. c)Thin walled fibers with distinctly bordered pits in tangential and radial walls. d)Axial parenchyma diffuse and diffuse-in-aggregates and rare paratracheal oil cells associated with axial parenchyma. e)Rays predominantly uniseriate, composed exclusively of procumbent cells with prismatic crystals.

Osteophloeum platyspermum (Figure 2 A-B): a) Growth ring boundaries distinct, slightly marked by thick-walled and radially flattening late wood fibers. b) Vessels diffuse; solitary and in radial multiples of 2-5 cells; simple perforation plates, intervessel pits alternate and vessel-ray pitting with much reduced borders to apparently simple. c)Fiber thin= to thick-walled with

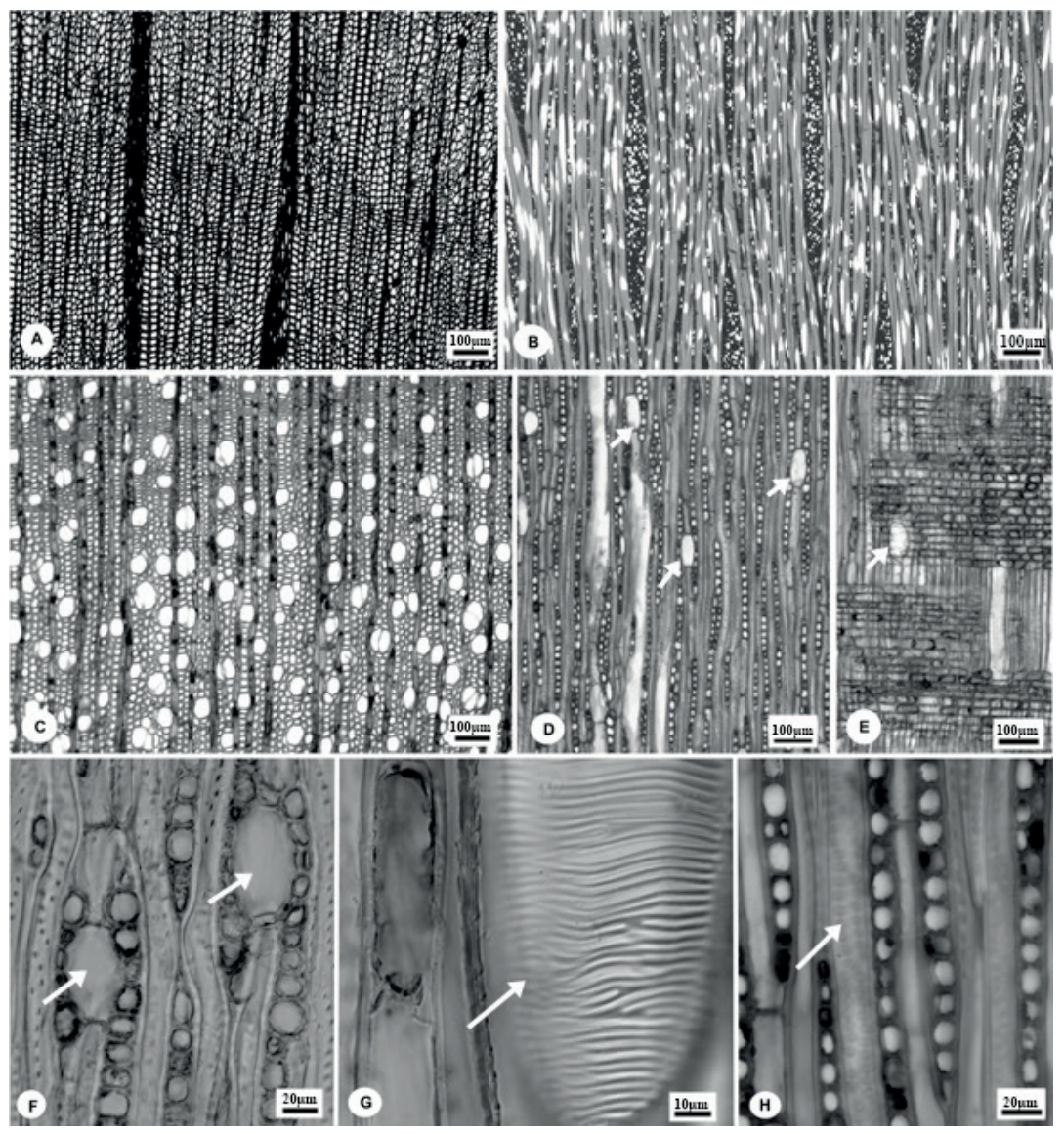

FIGURE I Optical images of the wood species. A-B: Drimys brasiliensis.A. Wood vesselless, axial parenchyma absent or scarce diffuse. B. Rays uniseriate and multiseriate. C-H: Capsicodendron dinisii. C. Vessels predominantly solitary, axial parenchyma diffuse and diffuse-in-aggregates, rare paratracheal. D-F. Oil cells associated with axial parenchyma (arrows). D,F-H. Rays predominantly uniseriate. F,H. Fiber with distinctly bordered pits (arrow). G. Scalariform plate in element of vessel (arrow). Transverse sections: A,C; longitudinal tangential sections: B, D, F-H; longitudinal radial sections: $E$. 
simple to minutely bordered pits in tangential and radial walls. d). Axial parenchyma scanty paratracheal and in narrowed bands or lines. e)Rays predominantly biseriate, occasionally with multiseriate portions as wide as the uniseriate portions and body rays cells procumbent mostly with I-4 rows of square/upright cells.

Rauvolfia sellowii (Figure 2 C-G): a)Growth ring boundaries indistinct or absent. b)Vessels diffuse, predominantly solitary or multiple of 2-3 cells, simple perforations plate, alternate intervessel pits and vesselray pitting with reduced borders to apparently simple. c) Fibers thin walled with distinctly bordered pits. d)Axial parenchyma diffuse and diffuse in aggregates. e)Rays predominantly three-seriate, uniseriate rays can be as wide as the multiseriate rays body ray cells procumbent mostly with 2-4 rows of square/upright marginal cells with prismatic crystals.
Simaba cedron (Figure 3 A-C): a)Growth ring boundaries indistinct or absent. b)Vessels diffuse, solitary and multiple of 2-5 cells, simple perforation plates, alternate intervessel pits and vessel-ray pitting with distinct borders similar to intervessel pits. c)Fibers thinto thick-walled with simple to minutely bordered pits. d) Axial parenchyma vasicentric and in bands with $5-8$ cells wide with prismatic crystals in subdivided parenchymal cells. e)Rays mostly biseriate; body ray cells procumbent occasionally with one row of square marginal cells.

Handroanthus serratifolius (Figure 3. D-E): a) Growth ring boundaries indistinct or absent. b) Vessels diffuse, solitary and multiple of 2-4 cells, simple perforations plate, alternate intervessel pits and vessel-ray pitting with distinct borders similar to intervessel pits. c)Fibers thick walled with simple to

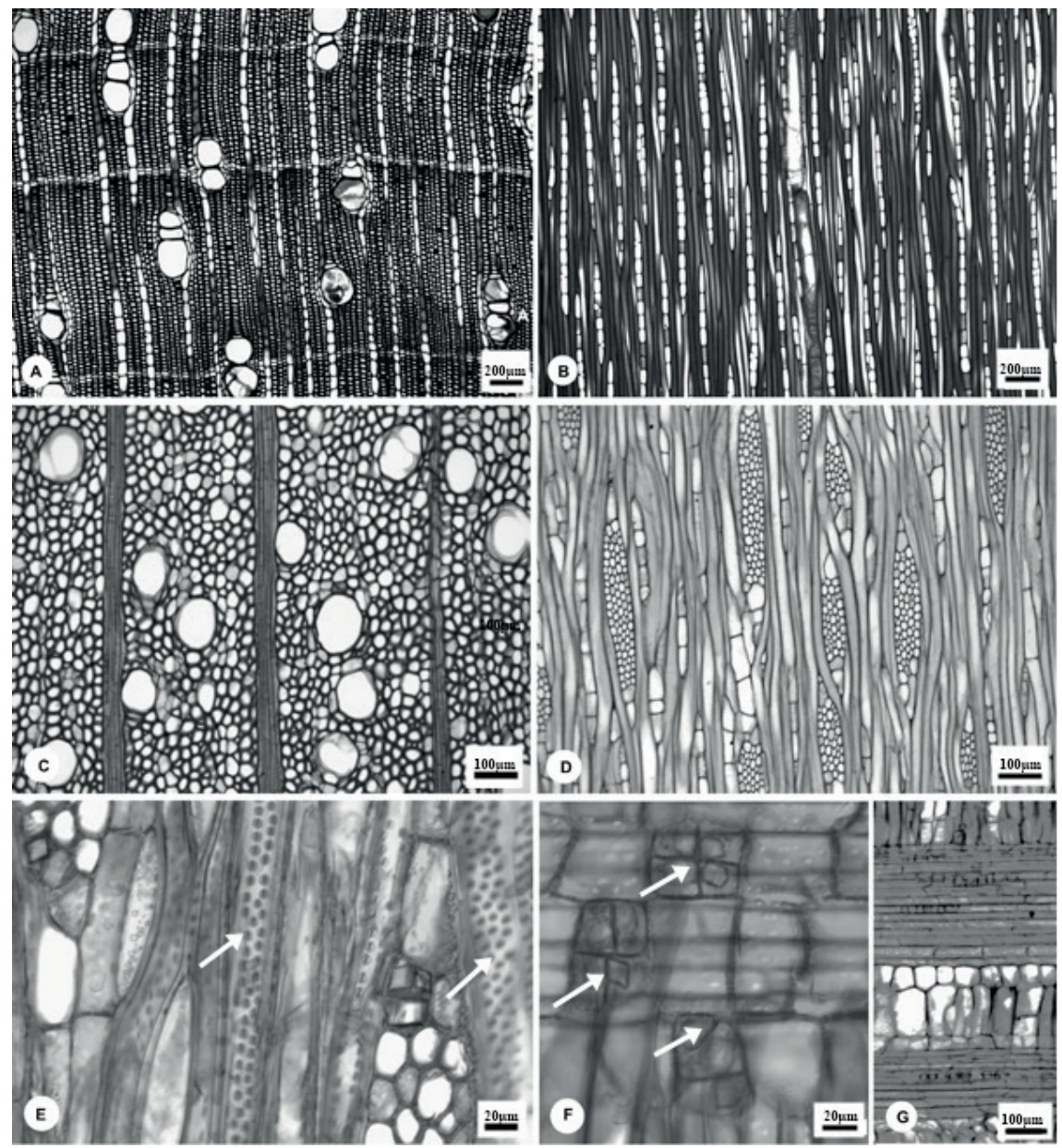

FIGURE 2 Optical images of the wood species. A-B: Osteophloeum platyspermum. A.Growth ring boundaries slightly marked by the flattening and thickening of the fibers, vessels solitary or multiple of 2-5 cells. B. Rays predominantly uniseriate. C-G. Rauvolfia sellowii. C. Vessels predominantly solitary, axial parenchyma diffuse. D. Rays homoseriate and multisseriate. E. Fibers with distinctly bordered pits (arrows). F. Prismatic crystals present in ray cells (arrows). G. Ray cells procumbent with square/upright marginal cells. Transverse sections: A, C; longitudinal tangential sections: B, D-E; longitudinal radial sections: F-G. 
minutely bordered pits. d)Axial parenchyma unilateral paratracheal and aliform with short and long confluences, usually forming bands. e). Rays predominantly biseriate, composed exclusively of procumbent cells. f). Rays and axial elements storied (Table I and 2).

Leptolobium dasycarpum (Figure 3 F-H): a)Growth ring boundaries indistinct or absent. b)Vessels diffuse; solitary and multiple of 2-5 cells, simple perforations plate, alternate intervessel vestured pits and vesselray pitting with distinct borders similar to intervessel pits. c)Fibers thick walled with simple to minutely bordered pits. d)Axial parenchyma apotracheal diffuse, paratracheal aliform and aliform confluent. e)Rays predominantly three-seriate, body ray cells procumbent, mostly with one row of square/upright marginal cells. f)Prismatic crystals in radial and axial parenchyma cells.

The measured anatomical parameters (quantitative data) are on Table I: Vessel diameter $(\mu \mathrm{m})$, Vessel frequency $\left(\mathrm{mm}^{2}\right)$, Ray width $(\mu \mathrm{m})$, Ray width in number of cells, Ray height in micrometers $(\mu \mathrm{m})$, Ray height in number of cells, and Ray frequency (linear millimeter). Most of the parameters showed significant difference at $5 \%$ of probability.

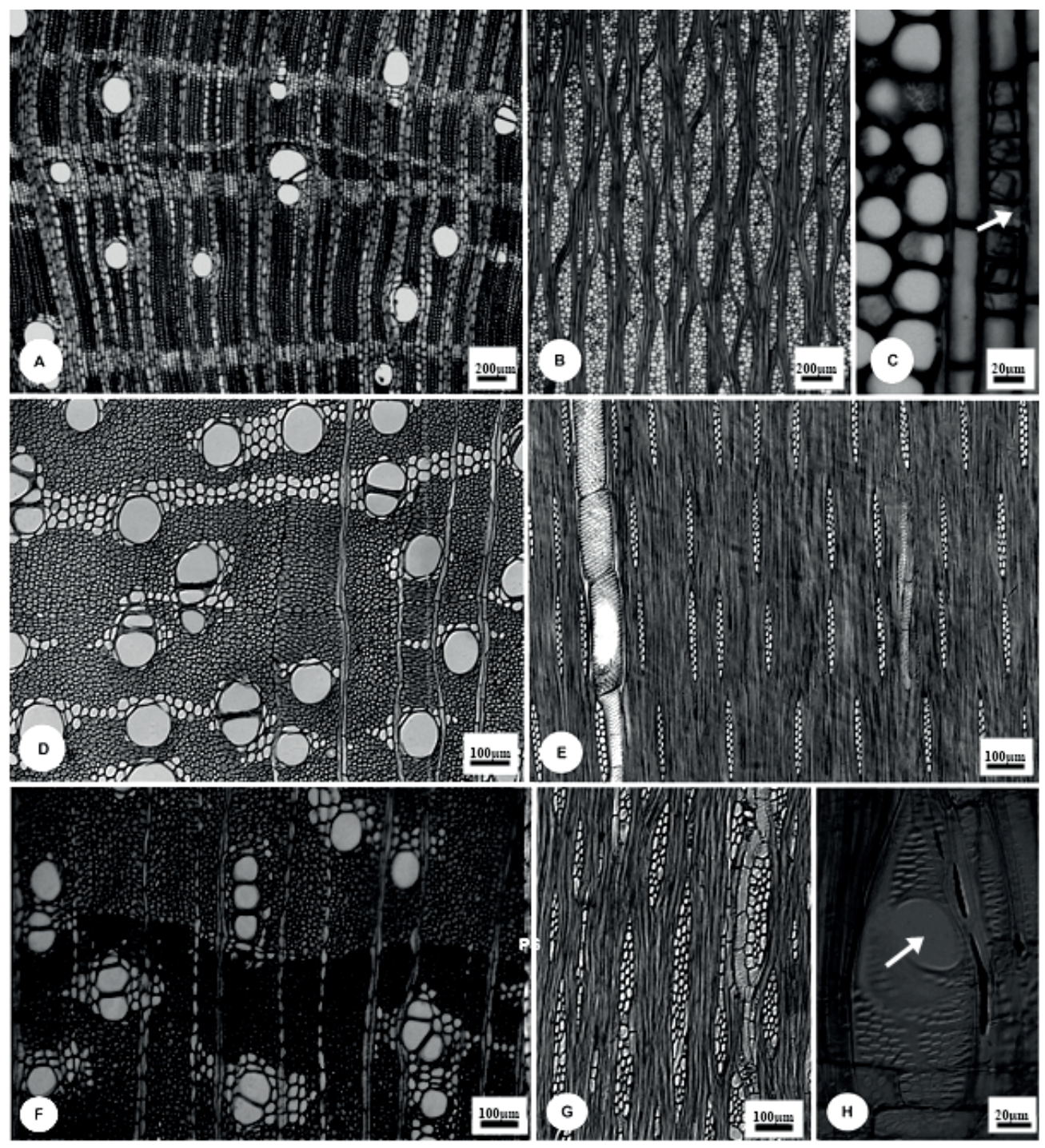

FIGURE 3 Optical images of the wood species. A-C: Simaba cedron. A.Vessels solitary and multiple, axial parenchyma vasicentric and in bands. B. Rays uniseriate and multiseriate. C. Prismatic crystals in parenchyma cells (arrow). D-E: Handroanthus serratifolius. D.Vessels solitary and multiple, axial parenchyma unilateral, vasicentric with short to long confluences. E. Rays predominantly biseriate, storied elements. F-H: Leptolobium dasycarpum. Vessels solitary and multiple, axial parenchyma aliform and aliform confluent. G. Rays uniseriate and multiseriate. H. Simple perforation plate (arrow). Transverse sections: A, D,F; longitudinal tangential sections: 2B-C, E, G; longitudinal radial sections: $H$. 
TABLE I Anatomical quantitative parameters of the wood species.

\begin{tabular}{|c|c|c|c|c|c|c|c|}
\hline & C. dinisii & O. platyspermum & R. sellowii & S. cedron & H. serratifolius & L. dasycarpum & $\mathrm{F} / \mathrm{p}$ value \\
\hline \multirow{2}{*}{ VD } & $44 \pm 9 e$ & $208 \pm 60 a$ & $110 \pm 19 c$ & $152 \pm 50 \mathrm{~b}$ & $147 \pm 29 b$ & $80 \pm 28 d$ & 185.80* \\
\hline & $2|-7|$ & $63-324$ & $52-|5|$ & $13-315$ & $65-209$ & $5-127$ & $p<.05$ \\
\hline \multirow{2}{*}{ VF } & $85 \pm 15 a$ & $2 \pm I d$ & $12 \pm 3 b c$ & $2 \pm 2 d$ & $7 \pm I b$ & $13 \pm 6 \mathrm{~cd}$ & $488.01 *$ \\
\hline & $62-105$ & $\mathrm{I}-5$ & $7-22$ & $\mathrm{I}-7$ & $5-10$ & $|-2|$ & $p<.05$ \\
\hline \multirow{2}{*}{ RW } & $21 \pm 6 d$ & $56 \pm 15 b$ & $50 \pm 17 b$ & $80 \pm 55 a$ & $33 \pm 10 c$ & $47 \pm 15 b c$ & $56.50 *$ \\
\hline & $8-40$ & $21-99$ & $8-90$ & $12-209$ & $|5-8|$ & $21-85$ & $p<.05$ \\
\hline \multirow{2}{*}{ RWC } & $\mathrm{I} \pm 0,4 \mathrm{c}$ & $2 \pm I c$ & $3 \pm 2 a$ & $2 \pm I b$ & $2 \pm I b$ & $3 \pm 1 a$ & $48.74 *$ \\
\hline & $\mathrm{I}-2$ & $1-3$ & $1-6$ & $1-6$ & $\mathrm{I}-4$ & $1-4$ & $p<.05$ \\
\hline \multirow{2}{*}{$\mathrm{RH}$} & $41 I \pm 196 c$ & $1077 \pm 43 \mid a$ & $420 \pm 146 c$ & $599 \pm 42 \mathrm{lb}$ & $263 \pm 36 d$ & $298 \pm 109 c d$ & 106.83* \\
\hline & $69-992$ & $37|-25|$ & $121-866$ & $|3-204|$ & $152-347$ & $138-577$ & $p<.05$ \\
\hline \multirow{2}{*}{$\mathrm{RHC}$} & $17 \pm 8 a$ & $I I \pm 6 b$ & $I I \pm 5 b$ & $15 \pm 10 a$ & $10 \pm 2 b$ & $9 \pm 4 b$ & $18.54 *$ \\
\hline & $3-40$ & $2-30$ & $\mathrm{I}-24$ & $\mathrm{I}-50$ & $5-15$ & $3-19$ & $p<.05$ \\
\hline \multirow{2}{*}{ RF } & $I I \pm I a$ & $5 \pm I c d$ & $4 \pm I d$ & $6 \pm \mathrm{lbc}$ & $6 \pm \mathrm{lb}$ & $6 \pm \mathrm{lbc}$ & 128.40* \\
\hline & $10-14$ & $4-6$ & $2-6$ & $4-7$ & $4-8$ & $4-7$ & $p<.05$ \\
\hline
\end{tabular}

Measured parameters: VD- Vessel diameter $(\mu \mathrm{m})$, VF - Vessel frequency (mm2), RW - Ray width $(\mu \mathrm{m})$, RWC - Ray width in number of cells, RH - Ray height in micrometers $(\mu \mathrm{m}), \mathrm{RHC}$ - Ray height in number of cells, and FR - Ray frequency (linear millimeter). The results are shown as: mean \pm standard deviation, maximum value - minimum value. The Tukey Test at a $5 \%$ probability level was applied. The averages followed by the same letter do not differ statistically between themselves. * Significant at a 5\% probability level; ns Non-significant ( $p>=.05$ ). Number of measurements $=20$.

TABLE 2 Anatomical qualitative parameters for the separation of the species.

\begin{tabular}{|c|c|c|c|c|c|c|c|}
\hline Parameters & Classes & A & B & C & D & E & $\mathrm{F}$ \\
\hline $\begin{array}{l}\text { Growth ring } \\
\text { boundaries }\end{array}$ & $\begin{array}{l}\text { indistinct or absent } \\
\text { distinct }\end{array}$ & * & $*$ & ** & *⿻丷木 & ** & * \\
\hline $\begin{array}{c}\text { Vessels } \\
\text { perforation plates }\end{array}$ & $\begin{array}{l}\text { scalariform } \\
\text { simple }\end{array}$ & * & * & * & * & * & * \\
\hline $\begin{array}{l}\text { Intervessel pits } \\
\text { arrangement }\end{array}$ & $\begin{array}{l}\text { opposite } \\
\text { alternate }\end{array}$ & $*$ & $*$ & * & * & * & * \\
\hline Vestured pits & & & & & & * & \\
\hline Vessel ray pitting & $\begin{array}{l}\text { similar to intervessel pits } \\
\text { reduced borders to } \\
\text { apparently simple }\end{array}$ & $*$ & $*$ & * & * & * & * \\
\hline $\begin{array}{l}\text { Fiber wall } \\
\text { thickeness }\end{array}$ & $\begin{array}{l}\text { thin-walled } \\
\text { thin- to thick-walled } \\
\text { thick-walled }\end{array}$ & * & * & * & * & * & * \\
\hline Axial parenchyma & $\begin{array}{c}\text { apotracheal difuse } \\
\text { diffuse and diffuse-in- } \\
\text { aggregates } \\
\text { unilateral paratracheal } \\
\text { vasicentric and in bands } \\
\text { scanty paratracheal } \\
\text { and in narrowed } \\
\text { bands/lines } \\
\text { paratracheal, aliform, } \\
\text { and aliform confluent }\end{array}$ & * & $*$ & * & * & * & * \\
\hline $\begin{array}{l}\text { Oil cell associated } \\
\text { with axial }\end{array}$ & parenchyma & * & & & & & \\
\hline $\begin{array}{l}\text { Ray cells } \\
\text { composition }\end{array}$ & $\begin{array}{c}\text { procumbent cells } \\
\text { procumbent, square } \\
\text { cells } \\
\text { procumbent, square/ } \\
\text { upright cells } \\
\end{array}$ & * & * & * & * & ** & * \\
\hline Crystals & & * & & ** & & & * \\
\hline Storied elements & & & & & & * & \\
\hline
\end{tabular}

A. Capsicodendron dinisii (Canellaceae), B. Osteophloeum platyspermum (Myristicaceae), C. Rauvolfia sellowii (Apocynaceae), D. Simaba cedron (Simaroubaceae), E. Handroanthus serratifolius (Bignoneaceae) and F. Leptolobium dasycarpum (Leguminosae).

\section{DISCUSSION}

Wood anatomy reveals, most of the time, anatomical features associated with specific groups of plants, since several taxa may have combinations of typical microscopic anatomical features (BAAS et al., 2000).

D. brasiliensis (Winteraceae), characterized by uniseriate and multiseriate rays, where the multiseriate rays are larger in height and width than the uniseriate ones (Figure I A-B), is a vesselless wood. The presence of tracheids and absence of vessel elements easily separated $D$. brasiliensis from the others species.

C. dinisii, with vessels predominantly solitary (Figure IA) and axial parenchyma displayed similarly to $R$. sellowii and $H$. serratifolius. However, it is possible to separate $C$. dinisii from the others by the presence of the scalariform perforation plate (Figure IG), intervessel pits opposite and the oil cells in the axial parenchyma (Figure I D-F). Scalariform perforation plates were also described by Majcher (2013) for C. dinisii. According to Wilson (1965) and Carlquist (1988), C. dinisii belongs to a basal family, Canellaceae, which, considering the trends of secondary xylem, presents primitive vessels elements with scalariform perforation plate. Quantitative data, such as vessel diameter, width and frequency of rays, were also helpful to separate these species, since $C$. dinisii has smaller vessels, narrower and more frequent rays than the others (Table I and 2).

0 . platyspermum is characterized by paratracheal vasicentric axial parenchyma in narrow bands or lines (Figure 2A) which marks the growth ring boundaries as discussed by Lisboa et al. (1984, 1987). These features, besides the ray width (Table I) can separate it from $S$. 
cedron, which shows a banded axial parenchyma. Only simple perforations were observed for this species. The two species, $O$. platyspermum and $\mathrm{S}$. cedron, are separated from the others for not having diffuse apotracheal parenchymal. Scalariform perforation plates and laticifers or tanniniferous tubes, although described for O. platyspermum by Insidewood (2004), were not observed in the samples.

$R$. sellowi has indistinct or absent growth ring boundaries, vessels with diffuse distribution, solitary and multiple vessels, simple perforation plate, paratracheal parenchyma, rays with 4 or more cells wide, body ray with procumbent cells and I-4 marginal rows of square/ upright cells (Figure $2 \mathrm{C}-\mathrm{G}$ ), as described by Alves and Angyalossy-Alfonso (2000, 2002). R. sellowii and L. dasycarpum can be separated considering the number of square/upright marginal cells, since $R$. sellowii (Figure 2 $D-G)$, has a larger number of cells, also, the uniseriate rays can be as wide as the multiseriate rays, differently from $L$. dasycarpum (Figure 3G). For S. cedron, on the other hand, exclusively procumbent cells on the rays was observed, and uniseriate and multiseriates rays (Figure $3 \mathrm{~B}$ ) have distinct size as well as in D. brasiliensis (Figure I A-B).

For $H$. serratifolius, it was observed that this species is easily separated from the others species by the presence of the unilateral paratracheal parenchyma (Figure 3D) and the stratification of the cell elements (Figure 3E). Most parameters analyzed match the descriptions of Alves and Angyalossy- Alfonso (2000, 2002), Trevizor (20II) and Albuquerque (20I2), as the presence of growth ring boundaries, vessels with diffuse distribution, solitary and multiple vessels, simple perforation, axial parenchyma apotracheal and paratracheal with short to long confluences, usually forming bands. Although Albuquerque (2012) describes the species as with scarce paratracheal aliforme, homocelular rays with 2-3 procumbent cells wide and presence of storied elements. Reticulate, foraminate, and/or other types of multiple perforation plates, as described by Insidewood (2004), were not observed.

L. dasycarpum is easily separated from the others by the presence of vestured pits. The presence of prismatic crystals is also an important feature. Crystals were observed in the ray cells of $R$. sellowii and $C$. dinisii while for $L$. daysidarpum they were present also in axial parenchyma series (Figure 3C). Insidewood (2004) described prismatic crystals in ray cells of Cinnamodendron axillare (Canelaceae).

Although the qualitative anatomical analysis show several features previously highlighted, by Carlquist
(1988) for D. brasiliensis, by Majcher (2013) for C. dinisii, by Lisboa et al. (1984, 1987) for O. platyspermum, by Detienne and Jacquet. (1983), Manieri (1958), Alves and Algyalossy-Alfonso (2000, 2002) and Miller (2007) for R. sellowii, and, by Alves and Algyalossy-Alfonso (2000, 2002,) Léon (2009), Trevizor (20II) and Albuquerque (20I2) for $H$. serratifolius, our results review some of the features, add description of species not yet investigated and give more emphasis to the quantitative features previously poorly explored. Thus, the results show that $D$. brasiliensis is separated from the others by the presence of tracheids. $C$. dinisii has scalariform perforations and oil cells associated with the axial parenchyma. The axial parenchyma paratracheal vasicentric and in marginal bands in $O$. platyspermum, beyond the rays width, can separate it from S. Cedron. $H$. serratofolius has the unique presence of the axial unilateral paratracheal parenchyma and storied cell elements. $R$. sellowii and $L$. dasycarpum can be separated from each other by the number of square/upright marginal ray cells, greater in $R$. sellowii.

\section{CONCLUSIONS}

When the seven species were compared, the uniqueness of some features is clear and shows how wood anatomy is a valuable tool to separate these species of distinct families. Drimys brasiliensis is separated from the others by the presence of tracheids. Capsicodendron dinisii has scalariform perforations plates and oil cells associated with the axial parenchyma. Axial parenchyma paratracheal vasicentric and in marginal bands beyond the rays' width, can separate Osteophoeum platyspermum fromSimaba cedron. Handroanthus serratifolius has the unique presence of the axial unilateral paratracheal parenchyma and storied cell elements (parenchyma, fibers and vessel elements). Rauvolfia sellowii and Leptolobium dasycarpum can be separated by the number of square/ upright marginal ray cells, greater in Rauvolfia sellowii.

\section{ACKNOWLEDGMENT}

The authors thank the Institute for Technological Research of São Paulo (IPT) for the wood samples, Antonio Franco Barbosa for expert assistance, the Museum of Zoology at the Federal University of Bahia for the use of optical equipment and the CNPq (Conselho Nacional de Desenvolvimento Científico e Tecnológico) for the financial support for the first author. Last but not least, the authors thank the reviewer for the comments and suggestions, which significantly contributed to improving the quality of the publication. 


\section{REFERENCES}

ANDRADE, M.A. Óleos essenciais de Cinnamodendron dinisii Schwacke e Siparuna guianensis Aublet: composição química, caracterização das estruturas secretoras e avaliação do potencial biológico. 2013 . 226 p. Tese de Doutorado em Agroquímica, Universidade Federal de Lavras, Minas Gerais.

ALBUQUERQUE, A.R. Anatomia comparada do lenho e do carvão aplicada na identificação de 76 espécies da floresta Amazônica, no estado do Pará, Brasil. 20I2. 250 p, Tese de Doutorado, Universidade de São Paulo, São Paulo.

ALVES, E.S.; ANGYALOSSY-ALFONSO, V. Ecological trends in the wood anatomy of some Brazilian species. I. Growth ring boundaries and vessels. IAWA Journal, v. 2I, p.3-30, 2000.

ALVES, E.S.; ANGYALOSSY-ALFONSO, V. Ecological trends in the wood anatomy of some Brazilian species. 2. Axial parenchyma, rays and fibers. IAWA Journal, v.23, p.39I418, 2002.

BAAS, P.; WHEELER, E.; CHASE, M. Dicotyledonous wood anatomy and the APG system of angiosperm classification. Botanical Journal of the Linnean Society, v. I34, n.I-2, p.3-17, 2000.

BARRERO, A.F; HERRADOR, M. M.; ARTEAGA, P.; LARA, A.; CORTES, M. Chemical composition of the essential oil from Drymis winteri First. Wood. Journal of Essential Oil Research, v. 12, n.6, p.685-688, 2000.

BARATTO, L.C; DUARTE, M. D. R.; SANTOS, C. A. D. M. Pharmacobotanic characterization of young stems and stem barks of Rauvolfia sellowii Mull. Arg., Apocynaceae. Brazilian Journal of Pharmaceutical Science, v.46, p.555-56I, 2010.

BARTH, O. M.; BARBOSA, A. F. Catálogo sistemático dos polens das plantas arbóreas do Brasil Meridional. XXI Canellaceae. Memórias do Instituto Oswaldo Cruz, v.74, n.2, 1976.

BITENCOURT, B. L. G.; LIMA, P. G. C.; BARROS, F. B. Comércio e uso de plantas e animais de importância mágico-religiosa e medicinal no mercado público do Guamá, Belém do Pará. Revista da Faculdade Santo Agostinho, v.lI, p.96-I58, 2014.

CAVALCANTE, P. B. Revisão taxonômica do gênero Simaba Aubl. (Simaroubaceae) na América do Sul. Conselho Nacional de Desenvolvimento Científico e Tecnológico. Publicações Avulsas do Museu Paraense Emilio Goeldi, v. 37, 1983.

CARLQUIST, S. Wood anatomy of Drimys ss (Winteraceae). Aliso, v. 12, p.8I-95, 1988.

CLAUDINO, V. D.; SILVA, K. C. D.; CECHINEL FILHO, V.; YUNES, R. A.; MONACHE, F. D.; GIMÉNEZ, A.; MALHEIROS, A. Drimanes from Drimys brasiliensis with leishmanicidal and antimalarial activity. Memórias do Instituto Oswaldo Cruz, v. I08, p. I40-I44, 2013.
GONZÁLEZ-COLOMA, Reina, M.; Sáenz, C.; Lacret, R.; Ruiz-Mesia, L.; Arán, V. J.; Martínez-Díaz, R. A. Antileishmanial, antitrypanosomal, and cytotoxic screening of ethnopharmacologically selected Peruvian plants. Parasitology Research, v. I I0, p. I38I-I392, 2012.

CORRÊA, D. S. Anti-leishmanial and anti-trypanosomal potential of polygodial isolated from stem barks of Drimys brasiliensis Miers (Winteraceae). Parasitology Research, v.109, p.23I-236, 20II.

DETIENNE, P.; JACQUET, P. Atlas d'identification des bois de l'amazonie et des regions voiseines. Centre Technique Forestier Tropical, Nogent s/Marne.1983, 640p.

HITOTSUYANAGI, Y.; OZEKI, A.; ITOKAWA, H.; DE MELLO ALVES, S.; TAKEYA, K. Cedronolactone E, a novel C(19) quassinoid from Simaba cedron. Journal of Natural products. v. 64, n. 12 , p. $1583-4,2001$.

INSIDEWOOD. Published on the Internet. http://insidewood. lib.ncsu.edu/search, 2004-onwards.

KRAUS, J. E.; ARDUIN, M., Manual básico de métodos em morfologia vegetal. Editora da Universidade Federal Rural do Rio de Janeiro, 1997, v. I, I98p.

LIMA, P. G. C.; COELHO-FERREIRA, M.; OLIVEIRA, R. Plantas medicinais em feiras e mercados públicos do Distrito Florestal Sustentável da BR-163, Estado do Pará, Brasil. Acta Botanica Brasilica, v.25, p.422-434, 201 I.

LISBOA, P. L. B.; LOUREIRO, A. A.; SILVA, J. C. A. D. Identificação macroscópica do lenho das Myristicaceae da Amazônia Brasileira. Boletim do Museu Paraense Emilio Goeldi, v. I, p.37-65, 1984.

LISBOA, P. L.; DA SILVA, J. C. A.; LOUREIRO, A. A.; GRACIELZA, M. D. A. Morphology of the vessel elements in the secondary xylem of the Myristicaceae from Brazilian Amazonia. IAWA Journal, v.8, p.202-2I2, 1987.

MAJCHER, J. C. Caracterização do xilema secundário de espécies arbóreas de um remanescente de floresta ombrófila mista, Curitiba, Pr. 2013. 37p. Monografia de conclusão do Curso de Ciências Biológicas, Universidade Federal do Paraná, Paraná.

MANIERI, C. Madeiras denominadas Caixeta. Instituto de Pesquisas Tecnológicas de São Paulo, 1958, n. 572, 94 p.

MILLER, R.B. Fluorescent woods of the world. in: Flynn, J.H. Jr. (ed.). A Guide to the More Useful Woods of the World. Forest Products Society, Madison, 2007. p.27I-305

MORAIS, S.M. et al. Plantas medicinais usadas pelos índios Tapebas do Ceará. Brazilian Journal of Pharmacognosy, v.15, p.169-177, 2005 
MORETTI, C. et al. Antimalarial activity of cedronin. Journal of Ethnopharmacology, v.43, p.57-6I. 1994.

OLIVEIRA, D. R.; KRETTLI, A. U.; AGUIAR, A. C. C.; LEITÃO, G. G.; VIEIRA, M. N.; MARTINS, K. S.; LEITÁ̃O, S. G. Ethnopharmacological evaluation of medicinal plants used against malaria by quilombola communities from Oriximiná, Brazil. Journal of Ethnopharmacology, v.15, n.173, p.424-34, 2015.

PRESIBELLA, M. M.; SANTOS, C. A. M; WEFFORT-SANTOS, A. M. Influencia de extratos hidroetanólicos de plantas medicinais sobre a quimiotaxia de leucócitos humanos. Revista Brasileira de Farmácia, v. 13, p.75-82, 2003.

RODRIGUES, V. E. G.; DE CARVALHO, D. A. Florística de plantas medicinais nativas de remanescentes de Floresta Estacional semidecidual na região do Alto Rio Grande Mina Gerais. Cerne, v. I4, p.93-I I2, 2008.

SEGOVIA, J. F. O.; GONÇALVES, M. C. A.; DE OLIVEIRA, V. L.; SILVEIRA, D.; KANZAKI, L. I. B. A Detecção de produtos naturais biologicamente ativos em espécies da flora do Estado do Amapá. Embrapa Amapá-Capítulo em livro técnico-científico (ALICE), $20 \mathrm{II}$.

SIENNA, C. Efeitos do extrato das cascas de Rauwolfia sellowii Müll Arg. e suas frações sobre a viabilidade e a melanogênese em células de melanoma murino B I6FI0. 2008, 78p. Dissertação de Mestrado em Biologia Celular e Molecular, Universidade Federal do Paraná, Paraná.
SILVA, F. A. S.; AZEVEDO, C. A. V. Versão do programa computacional Assistat para o sistema operacional Windows. Revista Brasileira de Produtos Agroindustriais, v. 4, n. I, p7I-78, 2002.

SOUZA, C. D. de, FELFILI, J.M. Uso de plantas medicinais da região de Alto Paraíso de Goiás, GO, Brasil. Acta Botânica Brasílica, v. 20, p.|35-|42, 2006.

TORRES, E.; WISNIEWSKI, J. R. A.; SIMIONATTO, E. L. Composição química dos componentes voláteis de Capsicodendron dinisii Schwancke (Canellaceae). Quimica Nova, v. 33, p. I30-132, 2010.

TREVIZOR, T. Anatomia comparada do lenho de 64 espécies arbóreas de ocorrência natural na floresta tropical Amazônica no estado do Pará. Piracicaba. 201 I, 216p, Dissertação de Mestrado em Tecnologia de Produtos Florestais, Escola Superior de Agricultura Luiz de Queiroz, Universidade de São Paulo, São Paulo.

WHEELER, E. A.; BAAS, P., GASSON, P. E. IAWA list of microscopic features for hardwood identification. IAWA Bulletin (ns), v. 10, p.219-332, 1989.

WILSON, T. K., 1965. The comparative morphology of the Canellaceae. II. Anatomy of the young stem and node. American Journal of Botany, p.369-378, 1965. 
